\title{
Professional development programmes for teachers moving from majority to minoritised language medium education: lessons from a comparative study
}

\author{
Joanna McPake ${ }^{1}$ - Wilson McLeod ${ }^{2}$. \\ Fiona O'Hanlon ${ }^{3}$ - Giovanna Fassetta ${ }^{4}$. \\ Mona Wilson ${ }^{5}$
}

Received: 13 December 2013/Accepted: 6 December 2015/Published online: 22 February 2016

(C) The Author(s) 2016. This article is published with open access at Springerlink.com

\begin{abstract}
Education through the medium of a minoritised language is widely regarded as a critical component of language revitalisation initiatives. Given the demographic and social position of many minoritised languages, however, it may not be easy to find teachers who are fluent and literate in the language, confident about using and teaching it, and prepared for the demands of working in classrooms where the language is the medium of instruction. This article presents findings from a comparative study of teacher education programmes adopted in Catalonia, the Basque Autonomous Community, Wales and New Zealand, to prepare teachers to teach
\end{abstract}

Joanna McPake

joanna.mcpake@strath.ac.uk

Wilson McLeod

W.McLeod@ed.ac.uk

Fiona O'Hanlon

Fiona.O'Hanlon@ed.ac.uk

Giovanna Fassetta

giovanna.fassetta@glasgow.ac.uk

Mona Wilson

mona.wilson@strath.ac.uk

1 School of Education, University of Strathclyde, Room 5.03 Lord Hope Building, 141 St James Road, Glasgow G4 0LT, Scotland, UK

2 Department of Celtic and Scottish Studies, University of Edinburgh, 50 George Square, Edinburgh EH8 9JU, Scotland, UK

3 Moray House School of Education, University of Edinburgh, Room 1.15 Charteris Land, Holyrood Road, Edinburgh EH8 8AQ, Scotland, UK

4 School of Education, University of Glasgow, St Andrew's Building, 11 Eldon Street, Glasgow G3 6NH, Scotland, UK

5 School of Education, University of Strathclyde, 5th Floor Lord Hope Building, 141 St James Road, Glasgow G4 0LT, Scotland, UK 
through the media of Catalan, Basque, Welsh and Māori respectively. The research was conducted to inform new professional development initiatives in Scotland, designed to enable qualified teachers to transfer from English-medium to Gaelicmedium education. The findings have wider relevance for other contexts in which the recruitment, professional development and retention of teachers to work in minoritised language medium education represent a challenge.

Keywords Minoritised language medium education - Teacher education and professional development · Scottish Gaelic · Basque · Catalan · Māori · Welsh

\section{Professional development for teachers in minoritised language medium education}

Minoritised language medium (MLM) education has long been seen as a central mechanism in language revitalisation strategies (Hinton 2001; McCarty 2002; May 2004; Tedick et al. 2011), although, as may commentators have cautioned (Fishman 1991; Baker 2001; Hornberger 2008), it is a mistake to think that such educational provision alone can successfully revitalise an endangered language.

Proponents of MLM education typically put forward three arguments in favour of its adoption. Firstly, in almost all language revitalisation contexts, the absence of educational provision for the language in question has contributed to its minoritisation and decline. The history of education in Scotland provides a good example of this phenomenon. When universal primary education was legally established in 1872, it was generally interpreted as meaning that provision should be wholly via the medium of English (Dorian 1981; Campbell 1950). As in other parts of the world, powerful arguments about the academic and social mobility benefits to accrue from acquisition of the dominant language were put forward, and contrasted with the perceived lack of value of the minoritised language. Though there were objections, and some provision for Gaelic both as a discrete subject and as the medium of instruction was made in a small number of schools in the first half of the twentieth century (An Comunn Gaidhealach 1936; Paterson 2003), it was not until the 1970s that bilingual primary education was piloted (Murray and Morrison 1984). During this period, from 1881 to 1981 , as UK Census data show, the numbers of Gaelic speakers fell from just under $7 \%$ of the Scottish population, or around 232,000 people, to $1.6 \%$ of the population (just under 80,000 people) (MacKinnon 1990). Though the decline of Gaelic cannot solely be attributed to the lack of educational provision in the language, it has been argued (e.g. MacKinnon 1978) that the (re-)introduction of education through the medium of Gaelic could make a major contribution to revitalisation. Similar arguments are put forward in relation to other minoritised languages, with the view that such provision has a critical role to play in ensuring that new generations retain or relearn the language in question.

Secondly, there is an extensive policy and research literature (UNESCO 1953; Skutnabb-Kangas 1981; August and Hakuta 1998; Thomas and Collier 2002; Lindholm-Leary and Borsato 2006; May 2013) arguing that children who are educated through the medium of their 'first' or 'native' language, or 'mother tongue', have 
greater academic success than those who are 'submerged' in a situation where the 'official', 'national' or 'dominant' language is the medium of instruction. ${ }^{1}$ For this reason, MLM education is seen as likely to improve academic outcomes for children for whom the minoritised language (ML) remains the pupils' 'first' language. This type of MLM education is often known as the maintenance model (Baker 2001; May 2008; García 2009).

Thirdly, it has become clear that in many contexts where the ML community is not sustaining speaker numbers by means of inter-generational transmission, successful language maintenance will also require children from families who do not use the ML at home to learn the language and to adopt this language as one of their own. Ferguson (2006) notes, in relation to processes of language acquisition in the case of such languages, that "teaching the regional language is seen as an essential complement to intergenerational language transmission within the family" (p. 34).

However, the complementarity of 'language transmission in the family' and 'bilingual education' as the two components of acquisition planning is the subject of much debate. Whilst Ferguson (2006), Baker and Jones (2000: 121) and Ó Flatharta et al. (2009: 4) perceive the two to be complementary aspects of language maintenance, other theorists, such as Fishman (1991), Spolsky (2008) and McCarty (2008), prioritise the home and community context, and view the school's role as a site of language acquisition as a means of re-establishing the self-sufficient maintenance of the target language through home and community language acquisition. McCarty (op.cit.) nevertheless concludes that "there are few instances of successful language revitalization in which schools have not played a crucial role" (p. 161).

Arguments promoting MLM education for children who are not (yet) fluent speakers can be seen as antithetical to those put forward for MLM education for those who are fluent. If education through one's 'first' language is a key factor in academic success, what then is the rationale for educating children who speak the 'dominant' language at home through the medium of the language they do not (initially) know? In this case, proponents point to the success of provision derived originally from the Canadian French immersion programmes (Lambert and Tucker 1972) and more recently from Content and Language Integrated Learning (CLIL) programmes which have been designed to enable school students to learn foreign languages (particularly English in countries where this is not the national language) to a high level of competence (Coyle et al. 2010; but see also Bruton 2011 and Cenoz et al. 2013, for critiques of the conceptualisation and outcomes of CLIL). Critically, pupils in such programmes are regarded not as 'submerged' but as 'immersed' in the language, and the outcome as 'additive' rather than 'subtractive' bilingualism. As they involve pupils developing oracy and literacy in both their

\footnotetext{
1 The use of inverted commas around terms used in this sentence and subsequently reflects the fact that these are widely used and understood but that each is controversial and the subject of considerable debate. The definition of an ML as a child's 'first' language can be particularly complex, given the likelihood that families where the ML is in use are often bilingual, using both the ML and the dominant language, and given social pressures to promote the learning of the dominant language as more 'useful' for the child in preparation for school. There is no scope to enter into more detailed discussion here, but see McPake et al. (2007).
} 
home language and the school language, this type of MLM education is sometimes referred to as the enrichment model (Fishman 1976; May 2008).

In a recent review article covering 40 years of indigenous language immersion education research, May (2013) has drawn attention to the fact that the combination of both language maintenance and enrichment approaches has produced hybrid classrooms where the ML is the 'first' language for some children while others are learners. He cites García's argument (2009: 118) that such a combination of 'first' and 'second' language learners, with their respective cultures and histories, will have an impact on the language, community and culture of the school language. García thus uses the term recursive for these programmes:

A recursive bilingual education theoretical framework supports the possibility of language revitalization through education ... acknowledging that language revitalization is not about going back to a past linguistic state but about recapturing a lost language and culture in the context of the present and in imagining the future. (quoted in May 2013: 44: emphasis in original; ellipsis in May's abbreviated quotation.)

May argues for a broader focus on indigenous immersion education, one which addresses not only the extent to which such educational provision contributes to the revitalisation of the ML but also the ways in which new linguistic and cultural relationships between the ML and the 'dominant' language are emerging as a result. This, he acknowledges, presents very significant challenges for teachers, whether in explicitly recursive programmes or in other types of immersion education.

This brief overview of major and ongoing debates concerning rationales and goals for MLM education provides an indication of the exceptional and, at times, contradictory demands made of teachers working in this sector. It goes without saying that such teachers need to be fluent speakers and literate in the ML in question, if they are going to use the language as the medium of classroom communication and instruction, and teach children to use the language for a variety of academic purposes. Yet where can such teachers be found in a context where previously there has been little or no specific teacher education provision to enable prospective teachers to acquire formal academic language skills in the minoritised language themselves and to learn how to pass them on to the next generation? What are the specialist pedagogical competences required to work in classrooms where some children are fluent speakers and others are learners of the ML, and how are high levels of academic attainment for all to be achieved among pupils of very mixed linguistic ability? To what extent is it feasible and legitimate to expect teachers to embrace the ideological mission of MLM education as a tool of language revitalisation, and to enrol pupils, not to mention their families and the wider community, in this endeavour? And how can they become agents of change, brokering new relationships between the ML and the 'dominant' language?

A number of commentators on MLM education (e.g. Stiles 1997; McCarty 2002; King and Benson 2004; May and Hill 2008) refer to the difficulties of finding fluent speakers to be teachers, and ensuring that they are appropriately trained and accredited. Much of this discussion focuses on the linguistic competence of prospective teachers, though Hamel (2008), Peter et al. (2011), Ó Laoire (2012) and 
May (2013) have drawn attention also to the need for MLM teachers to have specialist pedagogical training which enables them to work effectively in classrooms where the children's competence in the ML varies considerably, and more specifically to develop pupil literacy in both the ML and the 'dominant' language.

The present article aims to go some way to filling such a gap by outlining the nature of successful re-training courses available for majority language teachers to become minority language teachers within Wales, Catalonia, the Basque Autonomous Community and New Zealand. Common features of these programmes will be identified and discussed, with the intention that these inform future teacher education programmes in other contexts where such provision is currently lacking or in the early stages. Because the purpose of our research was to identify characteristics of successful practice which could transfer to the Scottish context, we have included discussion of specific points of comparison with Scotland, to illustrate how findings might apply elsewhere.

\section{Aims and methods of the comparative study}

The origins of this comparative study lie in a request from Bòrd na Gàidhlig, the statutory language planning agency for Gaelic in Scotland, to identify the factors contributing to the success of established MLM teacher education programmes, in the Basque Autonomous Community (BAC), Catalonia, New Zealand and Wales, which retrain majority language teachers to be teachers of the minoritised language. The aim was to inform Scottish policies to recruit and prepare qualified teachers currently working in the English-medium sector to transfer to Gaelic-medium education (GME). Although Initial Teacher Education for prospective GME teachers is well-established in Scotland it is not producing sufficient numbers of teachers (Robasdan 2006; Milligan et al. 2012) to meet current plans for expansion of the GME sector (Bòrd na Gàidhlig 2012).

The research approach consisted of a literature review for each of the four MLM education contexts and interviews with key stakeholders (e.g. policy makers and teacher education providers). The literature review focused on:

- teacher recruitment and retention investigating successful approaches targeting qualified teachers willing to undertake intensive study of the relevant ML and the pedagogical issues involved in teaching in MLM classes;

- linguistic competence addressing the level considered necessary to teach through the medium of an ML and the nature of existing intensive language courses and support mechanisms;

- language pedagogies for MLM classrooms considering the professional competences required by teachers to support (a) the linguistic development of pupils whose 'first' language is the ML and who are learning, formally and/or informally, the dominant language of wider society; (b) the linguistic development of pupils whose 'first' language is the dominant language and 
who are learning the ML in school, in what is for them a 'language immersion' setting; and (c) the emerging bilingualism of both sets of pupils.

Policy-makers and teacher education providers were consulted in each comparator context. They were asked to confirm that the main points drawn from the literature review were consonant with their own understanding of the context for MLM teacher education, and that the most authoritative sources had been included in the review. They were invited to supplement the review with contemporary information and insights into current developments and initiatives, with a particular focus on the development of intensive language programmes for teachers wishing to work in MLM education. These consultations were largely conducted via email, with senior representatives of language promotion and development agencies, specialist research centres, regional, national or specialist teacher education regulatory bodies with an overview of MLM education, and relevant teacher education providers.

Following the literature review and consultation with international experts, factors critical to the success of these initiatives were identified, and options for Scotland proposed. Scottish stakeholder perspectives on these options were then explored, through focus group discussions with prospective participants, a telephone survey of representatives of the local authorities (municipalities) responsible for implementing education policy at local level in Scotland, and face-to-face interviews with representatives of national organisations of relevance to Gaelicmedium education. This phase of the project is not presented in detail in this account, though in the final section, where we address lessons learnt from the review, we draw on these discussions. More detailed information can be found in the technical project report (McPake et al. 2013).

\section{Minoritised language medium teacher education in four contexts}

In this section, we present the main findings from the literature review and consultations with international experts, concerning Continuing Professional Development (CPD) for qualified teachers seeking to transfer to MLM education. Table 1 summarises essential points of comparison, in relation to Catalan, Basque, Welsh and Māori, and to our reference context, Gaelic in Scotland.

Some key differences between Gaelic and the other four languages are immediately apparent from this table. Gaelic is the language with the lowest number of speakers, and the lowest proportion relative to the immediate national or regional population. It also has the lowest number of children in MLM education and has recruitment difficulties in relation to its existing Initial Teacher Education programmes for Gaelic-medium education. To date there have been only smallscale initiatives targeting qualified teachers with an interest in transferring from English-medium education to GME. A more detailed discussion, including data sources, follows: 
Table 1 International comparisons of provision for Initial Teacher Education and Continuing Professional Development for Minoritised Language Medium education

\begin{tabular}{|c|c|c|c|c|c|}
\hline & \multicolumn{4}{|c|}{ Four well-established contexts } & \multirow{2}{*}{$\begin{array}{l}\text { Early stage } \\
\text { context } \\
\text { Gaelic }\end{array}$} \\
\hline & Catalan & Basque & Welsh & Māori & \\
\hline $\begin{array}{l}\text { Total } \\
\text { population }\end{array}$ & $\begin{array}{l}\text { Catalonia: } 7.5 \\
\text { million }\end{array}$ & $\begin{array}{c}\text { BAC: } 1.9 \\
\text { million }\end{array}$ & Wales: 3.1 million & $\begin{array}{l}\text { New Zealand: } \\
4.4 \text { million }\end{array}$ & $\begin{array}{l}\text { Scotland: } 5.3 \\
\text { million }\end{array}$ \\
\hline $\begin{array}{l}\text { ML } \\
\text { speakers }\end{array}$ & 5.3 million $(71 \%)$ & $\begin{array}{r}600,000 \\
\quad(32 \%)\end{array}$ & $562,000(19 \%)$ & $\begin{array}{c}132,000 \\
(3 \%)\end{array}$ & $\begin{array}{l}57,375 \\
\quad(1.1 \%)\end{array}$ \\
\hline $\begin{array}{l}\text { MLM } \\
\text { Education }\end{array}$ & $\begin{array}{l}\text { Virtually } \\
\text { universal }\end{array}$ & c. $55 \%$ & $\begin{array}{l}104,000 \text { pupils } \\
\quad(22 \%)\end{array}$ & $\begin{array}{l}\text { 16,792 pupils } \\
(2.2 \%)\end{array}$ & $\begin{array}{l}3522 \text { pupils } \\
(0.5 \%)\end{array}$ \\
\hline MLM ITE & All ITE in Catalan & $\begin{array}{l}\text { Well- } \\
\text { established }\end{array}$ & Well-established & $\begin{array}{r}\text { Recruitment } \\
\text { difficulties }\end{array}$ & $\begin{array}{r}\text { Recruitment } \\
\text { difficulties }\end{array}$ \\
\hline MLM CPD & $\begin{array}{l}\text { Reciclatge/FOPI } \\
\quad(\text { now historical })^{\mathrm{a}}\end{array}$ & IRALE $^{\mathrm{b}}$ & $\begin{array}{l}\text { Welsh Language } \\
\text { Sabbaticals } \\
\text { Scheme }\end{array}$ & $\mathrm{WKR}^{\mathrm{c}}$ & $\begin{array}{r}\text { Small scale } \\
\text { initiatives }\end{array}$ \\
\hline
\end{tabular}

\footnotetext{
${ }^{a}$ Formació Profesional Institucional (Institutional Professional Development)

b Irakasleen Alfabetatze Euskalduntzea (Teacher Literacy and Second Language Learning)

c Whakapiki i te Reo Māori (Promoting the Māori Language)
}

\section{Catalan}

\section{Population}

There are currently approximately 5.3 million Catalan speakers living in Catalonia, where they constitute $71 \%$ of the population (Idescat 2007). Catalan is the main medium of communication in media, publishing, administration and education, and its revitalisation, following a decline dating back to the eighteenth century and exacerbated during the Franco period (1939-75), is attributed to successful language education policy established in the 1980s, particularly the decision in 1998 to make Catalan the normal ${ }^{2}$ language of education in the region (Petherbridge-Hernández 1990b; Artigal 1997). It should be noted that many of those who do not currently speak Catalan are recent immigrants to the region, principally from other parts of Spain or from Latin America. Thus, while the Catalanisation of the long-established population may be regarded as virtually complete, there is an ongoing need to ensure that newcomers who speak Castilian (or other languages) learn Catalan (Escobar Urmeneta and Unamuno 2008).

\section{Catalan-medium education}

Historically, the shift from Castilian-dominant education to Catalan normalisation can be classified in three periods:

\footnotetext{
${ }^{2}$ Use of the term 'normal' in Spain has different connotations from English, going beyond the sense of 'usual' or 'habitual' to mean 'standard' or 'expected'. In addition, as some of the international experts consulted in this study have pointed out, 'normalisation' is a process strongly linked to the reestablishment of democratic practices in Spain following the death of Franco, and thus the move to make Catalan the normal language of Catalonia implies a key role for the language in this project.
} 
1. From 1978 to 1983

Initially, just $3 \%$ of schools in Catalonia were Catalan-medium. In the others, Catalan was introduced as a subject. By 1983, over $90 \%$ of all children in kindergartens and primary schools were learning Catalan as a subject for at least $4 \mathrm{~h}$ per week.

2. From 1983 to 1993

During this decade, three main types of schooling were available:

(a) Predominantly Catalan-medium instruction Catalan was the medium of instruction, with Castilian introduced from Grade 3 (age 8), when one subject was taught through the medium of Castilian. From Grade 6 (age 11), two Castilian-medium subjects were taught.

(b) Schools with bilingual instruction predominantly Castilian-medium in the early years, with $4 \mathrm{~h}$ per week of Catalan in kindergarten and Grades 1 and 2 of primary schools, followed by a progressive expansion of Catalan (as L2 and as a medium of instruction).

(c) Schools with predominantly Spanish-medium instruction Castilian was the language of instruction and Catalan was taught as a specific subject.

Decisions about which model to adopt were taken locally, but the Department of Education encouraged the adoption of the Catalan-medium model, and by 1990, $90 \%$ of schools were either 'predominantly Catalan-medium' or 'bilingual'.

3. Beyond 1993

A single model for kindergarten and primary schools was adopted. Catalan has now become the language of instruction while Castilian is introduced for the teaching of one subject from grade 3 and for the teaching of two subjects from grade 6 . There is, however, some flexibility and parents can demand that the first stage of teaching (3-7 years of age) is in Castilian, with a minimum of Catalan, as prescribed by the official policies (Woolard and Frekko 2012).

\section{Initial teacher education and continuing professional development for Catalan- medium teachers}

Since 1979 prospective teachers wishing to secure certification have been required to pass a Catalan proficiency examination. In recognition of the fact that although $50 \%$ of practising teachers could speak Catalan at that time, only a small proportion felt confident about teaching the language, reciclatge [recycling] courses were introduced to enhance teachers' oral proficiency in the language. These were run by institutes of educational sciences in three Catalan universities, from 1978 to 1986, and it is estimated that at their peak, some 20,000 teachers per year took part (van der Groot 1996). They were offered after hours at school locations throughout the academic year. An experimental project was launched in 1982, and later institutionalised in 1983 , to provide a more intensive reciclatge experience, the 
Formació Professional Institucional [Institutional Professional Development] (FOPI) Catalan language and culture programme. For a total of $8 \mathrm{~h}$ each week, four of which were during school day, teachers were immersed in Catalan while learning about different aspects of Catalan culture (Petherbridge-Hernández 1990a; Webber and Strubell i Trueta 1991).

The success of this retraining scheme, in combination with the requirement that all newly qualified teachers since 1979 should be fluent in Catalan, means that there is now no need to provide special Catalan language courses for qualified teachers seeking to work in Catalan-medium schools. Indeed, as noted above, Catalan has become the normal medium of instruction. This shift from Castilian-medium to Catalan-medium education over the course of some 30 years can be attributed to a number of factors:

- as Romance languages, Catalan and Castilian have many similarities which make it relatively easy for speakers of one to learn the other;

- the strong position of Catalan (compared to other MLs) when revitalisation through education was initiated in the 1980s: the language was widely spoken and $81 \%$ of the Catalonian population said they could understand Catalan, even though a lower proportion (64\%) said they could speak the language at that time (Gore and MacInnes 2000);

- widespread support for the revitalisation of Catalan as part of the democratisation process post-Franco;

- the flexible and supportive approach adopted in the introduction of Catalan medium in schools and in the training of teachers to work in Catalan medium classrooms, which evolved in collaboration with parents and teachers.

\section{Basque}

\section{Population}

The total population of the Basque Autonomous Community (BAC) ${ }^{3}$ is 1.9 million. Numbers of Basque speakers have risen from 419,200 in 1991 to over 600,000 in 2011 , or $32 \%$ of the population over the age of 16 (Basque Government 2012), an increase that is largely attributed to the success of Basque-medium education over this period (Cenoz 2012).

\section{Basque-medium education}

Moves to promote Basque-medium education date back to the early 1980s, following the death of Franco in 1975. Four models of provision were established: Model A (Castilian-medium with Basque as a second language), Model B (50\% Castilian, $50 \%$ Basque), Model D (Basque medium with Castilian as a second

\footnotetext{
${ }^{3}$ The BAC consists of three of the seven provinces that form the greater 'Basque Country' (Euskal Herria).
} 
language) and Model X (Castilian only). In 1983, some $80 \%$ of children were educated in the Castilian-medium Model A schools and $20 \%$ in Models B, D and X. By 2006, these percentages had been reversed, with the Basque-medium Model $\mathrm{D}$ the most popular choice; and it was projected that in school year 2013-14, $78 \%$ of pupils would be in Model D (Zalbide and Cenoz 2008; Gorter and Cenoz 2011; Tomé 2013).

\section{Initial teacher education and continuing professional development for Basque- medium teachers}

From the 1980s onwards, recruitment of teachers for Basque-medium education targeted already qualified teachers, both those who were fluent (native or nativelike) speakers of Basque and those with limited or no knowledge of the language. The Irakasleen Alfabetatze Euskalduntzea [Teacher Literacy and Second Language Learning] (IRALE) Programme has provided professional development for teachers wishing to transfer from Castilian- to Basque-medium education, ranging from $\mathrm{ab}$ initio Basque classes and literacy in Basque to acquisition of technical terminology for specialist subject areas. Teachers wishing to work in Model B or D schools needed to acquire a qualification (known as PL2), benchmarked against the Common European Framework (CEF) level C1. ${ }^{4}$ Between 1981 and 2007 almost 23,000 teachers took part in IRALE, and the proportion of primary and pre-primary teachers able to teach through the medium of Basque increased from about $20 \%$ to almost $90 \%$ (Zalbide and Cenoz 2008).

The IRALE programme, administered by the central Department of Education, was at its peak in the 1990s, when an annual average of over 1200 teachers were participating. Because most teachers working in the BAC now have PL2 from the outset of their careers, the focus of current IRALE provision is on developing teachers' advanced and specialist Basque rather than on entry-level competence.

The success of this scheme can be attributed to a number of factors:

- the political context (post-Franco), marked by the establishment of a federal system across Spain, focused on distinctive local characteristics (including Basque language and culture in the BAC) and the linking of these features to the commitment to democratic government;

- expectations among parents (whether or not from Basque-speaking families) that fluency in Basque would be a valuable future asset for their children, coupled with recognition over time that Model D schools were more successful than Model B in achieving high levels of competence in Basque;

- the declining school population in the BAC (Zalbide and Cenoz 2008), leading to possible concerns about redundancy among teachers and a willingness to

\footnotetext{
4 The Common European Framework of Reference for Languages: Learning, Teaching, Assessment (Council of Europe 2001) is a set of descriptors of progression in language learning. In widespread use across Europe, they have been used in some ML contexts to inform adult language qualifications and provision to enable learners to understand and advance their own linguistic progression. There are six levels, ranging from A1 (the lowest) to $\mathrm{C} 2$ (the highest).
} 
acquire new skills (chief among these the ability to teach through the medium of Basque) which would enable them to remain in employment;

- flexible and generous provision to enable teachers to acquire PL2: teachers with no Basque could take up to 3 years on full salary to learn the language through full-time study, and up to three further years of out of school hours support, to achieve the required level of competence (Macho Aguillo 2007; Zalbide and Cenoz 2008).

\section{Welsh}

\section{Population}

The current population of Wales is 3.1 million, of whom 562,000 people (19\%) are Welsh speakers (Office for National Statistics 2012). This proportion (approximately one-fifth of the population) has remained fairly stable since 1981, although the numbers of Welsh speakers have risen (as has the general population of Wales) over recent decades. However, over the last 20 years, there has been a very marked rise in the number of young Welsh speakers: $30 \%(169,000)$ of 3-15 year olds were Welsh-speaking in 2011, representing an increase of $49 \%$ in terms of speaker numbers in this age group, in comparison with the Census of 1991. This rise is mainly attributed (Jones 2012) to the success of Welsh language teaching in the schools, not only Welsh-medium provision but also in English-medium schools, where Welsh as a second language has been compulsory up to the age of 16 since 1999.

\section{Welsh-medium education}

Modern Welsh-medium education can be traced back to the 1930s, with significant expansion in the 1960s and again in the late 1980s, when Welsh was recognised as a core subject in Welsh-medium schools and as a second language in English-medium schools (Jenkins and Williams 2000). In Welsh-medium primary schools, teaching is predominantly in Welsh, while in Welsh-medium secondary schools, at least $50 \%$ of the subjects taught are offered in Welsh. Nationally, in the 2011-12 school year, there were 62,446 primary pupils in 461 Welsh-medium streams or schools, and 41,262 secondary pupils in 56 Welsh-medium secondary schools. These pupils constitute $24 \%$ and $21 \%$ of the mainstream school population for the primary and secondary school stages respectively (Welsh Government 2012a).

\section{Initial teacher education and continuing professional development for Welsh- medium teachers}

ITE courses for Welsh-speakers intending to work in the Welsh-medium education sector are long-established and successful. However, in 2003 the Welsh Assembly Government identified a need to recruit greater numbers of teachers to work in Welsh-medium schools, and the General Teaching Council for Wales proposed 
support for English-medium teachers wishing to transfer to Welsh-medium education. A pilot project ran in 2005-6, with the aim of equipping fluent Welshspeaking English-medium teachers with the profession-specific terminology and bilingual teaching methodologies required for transfer to the Welsh-medium sector. This Welsh Language Sabbatical Pilot Scheme involved 3 months of intensive training in the Welsh language and in bilingual pedagogy, and was funded by the Welsh Assembly Government. A positive evaluation (Dateb 2007) of the scheme led to its expansion. The Welsh Language Sabbaticals Scheme is currently available to full- and part-time primary and secondary teachers, further and higher education lecturers, and work-based learning training providers who are working in Wales. There are three course options available to fluent Welsh-speakers wishing to improve their Welsh-language skills for professional purposes:

(i) 'Higher Level' Block course-a 12-week full-time course, conducted through the medium of Welsh, providing participants with opportunities to improve their Welsh grammar and professional Welsh language skills, to develop relevant Welsh-medium teaching resources and to learn about bilingual teaching methodologies;

(ii) 'Higher Level' Distance-learning course-a 12-week part-time distancelearning course, intended for teachers with a strong command of spoken Welsh who wish to improve their written Welsh language capacities for professional purposes;

(iii) 'Integrated learning' course - a 12-week part-time course which aims to improve the Welsh language competences of secondary teachers working in Welsh-medium or bilingual schools.

However, although the scheme has been successful in improving the linguistic and professional competencies of those involved, an evaluation of the scheme conducted in 2011 noted that few teachers had transferred from English-medium to Welshmedium schools following the course (ARAD Consulting 2011). Most have continued to work in English-medium settings, where they may, for example, assume responsibility at school-level for the teaching of Welsh as a second language. In contrast to Scotland-or indeed to the early days of developing Catalan- and Basque-medium education-it appears that there has not been the same need to target beginners or intermediate level Welsh-speakers and provide intensive Welsh language input in order to secure sufficient numbers of teachers to work in the Welsh-medium sector. Undoubtedly this reflects both the larger Welshspeaking population, in comparison to the Gaelic-speaking population in Scotland and the long-term benefits of having secured Welsh-medium education for some 75 years, in comparison to the more recent introduction of Catalan- Basque-, and Gaelic-medium education. Despite the earlier concerns about teacher shortages, noted above, recent statistics indicate that there are no significant difficulties in filling posts in the Welsh-medium sector (Welsh Government 2012b). 


\section{Māori}

\section{Population}

The population of New Zealand is approximately 4.4 million, of whom just over half a million (15\%) claim Māori ethnicity, according to the 2006 Census. Of this group, 132,000 (24\% of the ethnic group) said they could hold a conversation in Māori. This represents a small decline in comparison with the censuses of 2001 and 1996, where the figure was $25 \%$. There is evidence also of generational decline. While a quarter $(25 \%)$ of the group aged between 15 and 64 could hold a conversation in Māori, almost half (49 \%) of those aged 65 and over could do so. In contrast, only one in six of those under the age of 15 said that they could hold a conversation in Māori (Statistics New Zealand 2007).

\section{Māori-medium education}

Māori-medium education was introduced in New Zealand in the 1970s, an initiative further promoted by the Māori Language Act of 1987, which made Māori an official language of New Zealand, and the Māori Language Strategy of 2003, a 25 year plan for the revitalisation of the language, in which Māori-medium education is seen as playing a significant role (Ministry of Māori Development 2003). However, recent figures indicate that the number of enrolments in Māori-medium primary and secondary schools has declined a little, from 17,422 in 2006 to 16,792 in 2012 (New Zealand Ministry of Education 2013b).

Provision for Māori includes both Māori-medium education and the teaching of Māori as a second language. In Māori-medium education, part or all of the curriculum is taught through Māori, via immersion (Māori language only) or bilingual (Māori and English) programmes. The former is referred to as Level 1 (81-100 \% Māori-medium) and the latter, Levels 2-4 (which range from 80 to $12 \%)$. In 2012, there were 276 schools in which Māori was the medium of instruction for over $50 \%$ of the time: 105 of which were Level 1 and the remainder, Level 2 (51-80 \% Māori-medium).

Educational policy for Māori-medium education in New Zealand differs in some respects from educational policy in the other contexts reviewed here. The educational attainment of ethnically Māori children is, on average, lower than that of New Zealanders of European descent (Pākehā). Māori-medium education has therefore been promoted not only for the purposes of language revitalisation but also as a way of raising educational attainment and of developing a distinctively Māori approach to curriculum content and pedagogical methods. This is a politically contested area, with some claiming that this provision is a necessary corrective to a long history of marginalisation and deprivation, while others argue that it does not reflect the social and cultural complexities of contemporary New Zealand (Rata 2012). In contrast to Wales, Catalonia, the BAC and Scotland, where take-up of MLM provision is not very specifically associated with a particular ethnic or cultural group, very few children who are not ethnically Māori are enrolled in Māori-medium education (3\% in 2012). Nevertheless, as a result of extensive 
provision for Māori as a second language at all levels of education, there are now some 30,000 people, not self-defined as ethnically Māori, who can speak the language, with varying degrees of competence (New Zealand Ministry of Education 2009).

\section{Continuing professional development for Māori-medium teachers}

The New Zealand Ministry of Education provides scholarships, called MāoriMedium Bilingual Education Study Awards, for postgraduate diploma-level study, allowing practising teachers to gain qualifications related to Māori language and culture. In 2012, 60 such awards were offered. The award includes paid time off in order to gain the qualification (up to a year), supply cover and help with university fees and relocation costs. Fluency in Māori, full teacher registration, a permanent position, and experience of teaching in a bilingual or immersion school are required in order to access the awards.

Retention of teachers working in Māori-medium education is an issue, as it has emerged that large numbers $(70 \%)$ of teachers leave Māori-medium education within 3 years of taking up post (Sharples 2013). The New Zealand Ministry of Education funds CPD for teachers working in Māori-medium education, Whakapiki $i$ te Reo Māori [Promoting the Māori Language] (WKR). Although this course includes opportunities to improve Māori language skills, the emphasis is on developing pedagogical competences. Initially the programme was universitybased, but is now school-centred, and involves all school staff (teaching staff, support and ancillary staff). Five educational providers co-ordinate WKR programmes in different regions, working with groups of staff over a period of a year. A recent evaluation (Matamua 2012) indicated that participants have found the programmes effective in terms of improving their own Māori language skills, increasing both the amount of Māori they use with pupils and the quality of the language, and in developing their classroom practice. Given the school-based focus of current programmes, broader issues of impact on the whole school and the wider community (for example greater emphasis on local Māori varieties) have also been evaluated positively. However, teacher retention remains a challenge, and the evaluators noted that data about the impact of WKR programmes on children's learning had not been collected.

The New Zealand context in some ways offers the closest comparison to Scotland, in that the proportion of Māori speakers in relation to the national population is very low, (though still over double that of Gaelic speakers in Scotland) and thus the challenge of recruiting fluent speakers as teachers for Māori-medium education is significantly greater than in the other MLM education contexts reviewed here. The New Zealand government has responded by providing incentives for Māori speakers to undertake ITE and post-graduate level study for Māori-medium education, and developing the national CPD scheme (WKR) described above. However, there are some critical differences between the Scottish and the New Zealand contexts, most notably the lower rates of educational attainment of pupils of Māori ethnicity compared with Pākehā and the high teacher drop-out rate from the Māori-medium sector. The current focus of WKR on 
developing whole school and wider community approaches to professional development for all staff (not only teachers) working in Māori-medium schools may prove effective over time: it is probably too soon to determine its impact.

\section{Critical factors in establishing effective provision for minoritised language medium teacher education}

Each of the four contexts reviewed above can be said to have made significant progress towards establishing effective provision for majority language medium teachers to transfer to MLM education. These schemes have produced a number of linguistically and professionally competent MLM teachers, contributing to the maintenance or expansion of provision for MLM education over several decades. While commentators in each context have been reluctant to describe the current position as successful, in the sense that each step in the revitalisation process produces new challenges, from the perspective of others who are still in the relatively early stages of developing such provision, there are valuable lessons to be learned from these pioneers.

Our analysis identified six features which contribute to the establishment of effective provision:

- critical mass in terms of the numbers of ML speakers in relation to the wider population;

- popular support for change;

- significant funding to support MLM teacher education;

- teacher commitment to language revitalisation through MLM education;

- long-term vision for the revitalisation of the ML, incorporating recognition of MLM education as a significant factor in growing the next generation of speakers;

- willingness to adapt and develop the focus of MLM teacher education over time.

Each of these features is discussed below.

\section{Critical mass}

Programmes to develop an MLM teacher workforce have been easier to establish in Catalonia, the BAC and Wales than in New Zealand and Scotland, because a significantly greater proportion of the population spoke the languages in question at the start of these initiatives. What, precisely, constitutes 'critical mass' in this context remains to be established. In particular, we need to be careful in defining the community within which a proportion speak the MLM in question. We have presented figures relating the number of speakers of Gaelic and Māori to the Scottish and the New Zealand populations as a whole (as has been conventional for each context) but it might be more appropriate to consider the strength of these languages in relation to the communities where they are most likely to be spoken (i.e. specifically amongst those of Māori descent in New Zealand, as opposed to the 
total population, or in the 'Gàidhealtachd' - the Gaelic speaking 'heartlands' - in Scotland). Nevertheless, given that the revitalisation of these languages are seen as national projects in these and other cases, the absence of a substantial section of the population who are already fluent speakers of the ML means that there are likely to be only a small number of practising teachers sufficiently competent in the ML to be recruited to these retraining programmes.

Moreover, precisely because MLM education has had a positive effect on the revitalisation of Catalan, Basque and Welsh, in terms of increasing the number of young speakers of these languages, this has created virtuous circles whereby the need for special schemes to recruit and prepare teachers of the majority language to be MLM teachers has become progressively less pressing. The issue of retraining teachers to work in MLM education is now only of historical interest in Catalonia, and the BAC, whilst re-training provision in Wales, although still in existence, is not a large source of Welsh-medium teachers. This situation does not affect the viability of the Welsh-medium sector, however, due to sufficient teacher supply from initial teacher education provision.

In contrast, in New Zealand and Scotland, the proportion of children currently enrolled in MLM education is lower than the proportion of speakers of Māori and Gaelic in the population, suggesting that further decline of these languages is likely unless MLM education provision expands. There is thus a risk of vicious cycle in both countries, suggesting that proactive policy and investment in MLM teacher education is required if current national plans for language revitalisation through MLM education are to succeed.

\section{Popular support for change}

In Catalonia and the BAC, ML revitalisation and associated MLM education programmes benefited from popular support for change, following the Franco period. Linguistic pluralism has been strongly associated with normalisation and the reintroduction of democratic processes. Thus political decisions to fund MLM teacher education and other structural developments to ensure the success of these programmes, such as corpus planning or the development of professional language qualifications, have been widely supported. The current context is somewhat different. There are challenges to the growing status of Catalan (Woolard and Frekko 2012) and Basque (López García 2009; Nationalia 2009). Their role is complicated in contexts where the numbers of Castilian-speaking immigrants to Catalonia (Pujolar 2010) and the BAC (Intxausti et al. 2013) are increasing, and where high levels of fluency in English are seen as critical for academic and career success, within a much less favourable economic climate for Spain as a whole. For these reasons there is a growing interest in both Catalonia and the BAC in trilingual education, combining Catalan or Basque respectively with Castilian and English. (For developments in trilingual education in Catalonia see Escobar Urmeneta and Unamuno 2008; Pérez-Vidal and Juan-Garau 2011; in the BAC, see Cenoz 2005; Lasagabaster nd; Cenoz and Etxague 2011).

Revitalisation programmes in Wales and New Zealand have been motivated by different phenomena, perhaps more similar to the Scottish context, where renewed 
interest in cultural and linguistic heritage and a concern about the potential for the MLs in question to disappear entirely, have all played a part in contributing to the (re-) introduction and growth of MLM education. It could be argued that this process has been more tentative in Scotland than in Wales or New Zealand, perhaps because Gaelic has been less strongly associated with national identity in Scotland than Welsh in Wales, or less identified with a distinctive cultural group, as with Māori in New Zealand. However, political support for Gaelic has grown in recent years, with all parties supporting the Gaelic Language (Scotland) Act 2005 and related initiatives, such as the National Plans for Gaelic, the first of which (2007-12) set out a vision for Gaelic becoming "the preferred language of an increasing number of people in Scotland", and proposed "an increase in the uptake and availability of Gaelic medium education" as one of the means by which this vision can be achieved (Bòrd na Gàidhlig 2007, p. 12); while the second (2012-17) establishes specific targets for the expansion of GME (Bòrd na Gàidhlig 2012, p. 8). Recent research (O'Hanlon et al. 2013) has shown much stronger positive public attitudes towards Gaelic and to GME in Scotland than were previously thought to exist. This may indicate that this is a propitious moment to promote greater commitment to revitalisation and particularly to the expansion of GME and the teacher education programmes that this would require.

\section{Significant funding}

In the four contexts reviewed here, there have been significant financial commitments supporting MLM teacher education. Given the different historical periods in which funding was allocated, variations in the education systems concerned and diverse time-scales, a clear indication of costs is difficult to achieve, but we summarise here the most relevant considerations:

\section{Catalonia}

The direct costs of the Reciclatge FOPI programme appear to have been relatively low. Teachers spent $8 \mathrm{~h}$ a week on the course, four of which were in their own time, and four of which were taken from their school time commitment but were covered by student teachers. Nevertheless, there was very significant investment in structures supporting implementation, including the establishment of adult language qualifications and a broad-based adult education programme; the shift from Castilian-medium to Catalan-medium ITE; the creation of other specialist university courses for language professionals, such as language planners; and the setting up of bodies to develop and promote specialist and technical language, notably TERMCAT, which develops new terminology in Catalan, including terminology of specific relevance to the education system.

\section{Basque Autonomous Community}

In the BAC, the scale of the retraining programme is striking. Participating teachers were allowed up to 3 years out of school to learn Basque, and up to three further 
years in their own time, to reach the required linguistic standard. The costs of the courses and of supply cover for teachers taking part were borne by the Department of Education in the BAC: in 2004, the budget for this was over $€ 36$ million (Gardner 2005). As with Catalonia, there have been similar investments in support structures, and the current focus of the IRALE programme is in co-ordinating these developments (corpus planning, language examinations, and advanced professional development for Basque-medium teachers).

\section{Wales}

The Welsh Language Sabbaticals Scheme aims to develop the linguistic and pedagogical skills of teachers, and other educational professionals (such as classroom assistants, and tertiary education lecturers). Courses are available at three levels: Higher (for fluent speakers of Welsh), Foundation (for those with a basic knowledge of Welsh), and Entry (a course specifically for classroom assistants working in English-medium or bilingual classrooms), with courses taking between 18 and 60 days. The budget for the Welsh Language Sabbaticals Scheme was £6 million for 2011-14.

\section{New Zealand}

The New Zealand education budget for 2013-14 allocates NZ \$3 million to support mentoring and professional learning in Māori-medium education, while additional initiatives to support Māori-medium education are specifically mentioned under other broader budget headings (New Zealand Ministry of Education 2013a).

In each of the four comparators, substantial amounts of money have been allocated to teacher education, directly or indirectly. It seems unlikely that provision can develop and grow significantly without investment at critical points in the development of MLM teacher education.

\section{Teacher commitment}

The commitment of teachers and of the broader education system to the cause of MLM education is undoubtedly a critical factor in the recruitment and retention of MLM teachers. Our review suggests that teacher commitment in Catalonia, the BAC and Wales has been high, and remains so, for a variety of reasons, both ideological and pragmatic. Moreover, in Catalonia, the BAC and also in Wales, opportunities for career-long engagement with MLM education are evident. In all three contexts, teachers can be confident that there will be jobs in the sector and that there are opportunities for career advancement within schools and in the wider system, for example in resource development or corpus planning.

In Scotland (as in New Zealand), the question of teacher commitment is more challenging. Although popular support for Gaelic-medium education may be on the rise, as discussed above, there is no catalyst, as there was in Catalonia and in the BAC, likely to bring about a sudden shift to attract English-medium teachers to GME. Though there may be a degree of awareness of plans to expand the sector, 
probably only a few teachers working in English-medium education will see this as a significant opportunity, and certainly none will be concerned that their current jobs are at risk. This indicates that the recruitment drive for practising teachers to move into GME may need to draw attention both to the ideological context for the expansion of GME, to recruit those who share those objectives, and to the long-term career opportunities-which therefore need to be secured.

\section{Long-term vision}

The success of MLM education, and role that effective teacher education programmes have played in this, needs to be understood as part of a long-term strategy in Catalonia, the BAC and Wales. Catalonia and the BAC have made very remarkable progress over a period of 30 years, as a result of having taken a longterm perspective from the outset. In Wales it can be argued that the current equilibrium has been achieved as a result of even longer-term planning, dating back to the late 1930s with periodic review and refocusing in the 1960s, the 1980s and the 2000s.

In both Scotland and in New Zealand, language planning is of more recent date, with the Māori Language Strategy published in 2003 and the first National Plan for Gaelic in 2007. As indicated above, such national and local plans for Gaelic may be beginning to change public perspectives and thinking within local authorities and national education bodies in relation to GME. However, there may be a need for more overt linking of the broad commitment to maintaining and promoting Gaelic to the crucial role of GME in securing the next generation of Gaelic speakers. For this reason, the complexities of the relationship between MLM education and the success of broader ML revitalisation initiatives, alluded to earlier in this article, may need to be more widely aired and investigated. If MLM education is accepted as having a critical role to play, then the importance of recruiting and retaining teachers for the sector becomes clear, as well as long-term planning specifically in relation to MLM teachers' professional needs and aspirations.

\section{Willingness to adapt and develop over time}

In Catalonia, the BAC, Wales and New Zealand, provision to support MLM teacher education has adapted to changing circumstances over time. For example, in the BAC, where IRALE began as provision to enable teachers with little or no Basque to become fluent enough to teach through the medium of the language, provision has evolved to concentrate more specifically on the development of educational resources, advanced skills in technical Basque for specialist subject areas and quality assurance strategies. There is recognition also that the success of Basquemedium education, which initially envisaged take-up only or mainly among pupils from Basque-speaking families, means that teachers now need to address more directly the needs of pupils who are learners of Basque, for whom the provision is, effectively, language immersion; and that this requires specialist training. Similar trends are observable in Wales and Catalonia. 
In addition, in both the BAC and Catalonia, there is a current focus on teacher education to support the inclusion of immigrants in Basque- and Catalan-medium schools, and on the growing demand for a trilingual approach, incorporating English as well as Castilian. In Wales, the 'Triple Literacy' initiative similarly seeks to exploit synergies for primary school pupils already bilingual in Welsh and English to learn a third language (Welsh Assembly Government 2011b).

In New Zealand, the focus of professional development has responded to the specific issue of support for Māori-medium teachers in the early years of service. It is recognised that this is a stage at which mentoring and support to develop professional linguistic and pedagogical skills are critical to long-term teacher retention. In addition, the locus of provision for professional development has shifted from universities to schools and school clusters, so that provision fits with headteachers' school development plans and so that the whole school and the wider community served by the school can be actively involved (Matamua 2012).

\section{Conclusions}

The research described here was undertaken to identify lessons for Scotland-and by extension other contexts where MLM teacher education is still at a relatively early stage of development-from pioneering programmes elsewhere. It is, of course, important to recognise that each of the examples reviewed here is a product of unique local, political, cultural and historical factors that cannot necessarily be reproduced elsewhere. For example, the presence of a critical mass of ML speakers in a position to become teachers at the point at which MLM programmes are introduced was clearly beneficial in Catalonia, the BAC and Wales, and equally clearly, lack of critical mass in Scotland and New Zealand presents an obstacle, not easily overcome. We have drawn attention above to the replication of 'virtuous' and 'vicious' cycles in these circumstances. Though it is not possible to create critical mass where none exists, understanding that this has been a significant factor elsewhere is important, as is an appreciation of the risk that a vicious cycle is in operation. To break out of such a cycle, where there are insufficient numbers of 'native' ML speakers, there is a clear need for investment in provision that enables ML learners to achieve very high levels of fluency in the language, perhaps specifically targeting those willing and able to become MLM teachers in future. This was, effectively, the decision taken in the BAC, in the early stages of the development of Basque-medium education, and the de facto model which emerged there-up to 3 years of intensive provision, and up to three further years of language study in personal time-may serve as a guide to the resource required to achieve this.

In relation to some of the other factors identified, the lesson to be learnt is perhaps to 'seize the moment'. Both Tollefson (1991) and Blommaert (1996) have argued that language policy and planning cannot be divorced from the sociopolitical context. We have seen that teachers in Catalonia and the BAC became engaged in the shift to MLM education as a result of changes in the wider political 
context, and took on the role of contributors to a new, democratic and plurilingual society. In Scotland, the ideological appeal to teachers to work in GME as Gaelic language champions has, to date, been more muted. This partly reflects the fact that Gaelic is not as strongly associated with Scottish identity as is probably the case with Catalan, Basque or Welsh in their respective contexts. Perhaps the proponents of Gaelic need to be bolder. In hindsight, the move towards the greatly increased roles of Basque and Catalan in Spain seems inevitable, but this was not the case in the immediate post-Franco period, when many threats to the MLM education project (in the broader context of the move towards the re-establishment of a democratic state) were posed. (For a political overview and the emergence of 'regional' languages as part of the shift to democracy, see Conversi 2002.) In any case, MLM education proponents need to understand what does, and what might, motivate teachers working in the 'dominant' language education sector to learn the ML and decide to dedicate their careers to the promotion of the language, to ensure that their political, ideological or cultural goals are shared by the ML-speaking community, and to publicise these shared aspirations more widely.

In addition, pragmatic expectations need to be met. MLM teachers should expect (at least) the same conditions of service as those working in 'dominant' language medium provision. This entails opportunities for professional development, security of tenure and promotion, as well as the same support structures, resources, quality assurance mechanisms that apply elsewhere. In addition, there are specialist forms of support for MLM education, including ML resource production and corpus planning, and the work of curriculum developers, examiners and inspectors who are familiar with the sector and aware of the challenges. Investment in all of these infrastructural elements is critical, as the research presented in this article makes clear.

In this context, current developments in New Zealand are of particular interest because they demonstrate a different approach to CPD compared to Catalonia, the BAC and Wales. The focus in Catalonia and the BAC, initially, was on ensuring that teachers were linguistically competent to teach through the medium of Basque or Catalan; now it has shifted to the development of advanced and specialist linguistic competence. The situation in Wales appears to be similar. There appears to have been less attention to the question of how, culturally, an MLM school differs from its neighbour where the dominant language is the medium of instruction. Historically, in New Zealand, the cultural dimension has been much more salient. For example, the Māori pre-school movement, Te Kōhanga Reo, which spearheaded the development of Māori-medium education in the 1980s, includes among its core principles not only full immersion in Māori but also the imparting of Māori cultural and spiritual values and concepts, the teaching and involvement in Māori customs, and the use of traditional child-care techniques (Sharples 1988, cited in May 2013; see May 2013 for an extended discussion of the Māori educational philosophy underlying Māori-medium programmes). In particular, there is a strong commitment to local autonomy for Māori-medium education and the active involvement of the wider community (whānau) and community elders (kaumātua) in decision-making. This undoubtedly underpins the shift from university-based CPD to school-centred 
CPD involving not only the teaching staff but support staff and the whānau. Although May and Hill (2008, p. 87) have queried whether community-based CPD initiatives might not be counter-productive, if unconnected to the research literature on effective provision, this model, where university staff work with school and whānau may succeed in combining the strengths of both sides.

This draws attention to the extent to which all education professionals, ranging from the school administrators who are the front-line mediators for children, parents, teachers, and visitors on a day-to-day basis, to specialists such as education psychologists, social workers or careers advisers, need to support the goals of MLM education, and how pupils' families and the wider community are engaged in the initiative. De Korne (2010: p. 117), writing about provision for indigenous languages in the USA and Canada, and citing Abele et al. (2000), May and Aikman (2003) and Crawford (1998), argues that community control or engagement with MLM education should be seen as a critical factor in achieving success. Huss (2008: p. 76) similarly comments: “...it is important to stress the need of the endangered language communities to form and steer their own language revitalization movements in order to gain lasting results." This raises questions-beyond the scope of this article-about who can be regarded as constituting the 'language community', particularly in contexts where there is no clear ethnic affiliation with the language, and where revitalisation initiatives seek to enrol families with very varied histories of speaking the language-including those with no history at all-as appears largely to be the case in the European examples reviewed here.

Lastly, it seems important to ensure that MLM education, particularly when it makes up only a very small part of the national system, does not become an educational backwater, overlooked or misunderstood in the wider context and rarely at the forefront of educational reforms. If MLM teachers feel neglected, they may lose commitment or feel that it does not matter what they do. This is a two-way issue. On the one hand, at the point of formulation, new educational developments must take into account the needs and aspirations of MLM education, and their impact on the sector must be evaluated; on the other, those working in the sector need to ensure that they are playing an active part, engaging in the debate, ensuring that their concerns, and their specialist expertise, are acknowledged and included. In this way, teachers and other educational specialists working in 'dominant' language medium education will become more aware of issues and developments, more attuned to differences and more engaged and committed to positive outcomes.

Acknowledgments The authors wish gratefully to acknowledge funding from Bòrd na Gàidhlig, the statutory language planning agency for Gaelic in Scotland, which enabled us to conduct this research. We also wish to acknowledge the invaluable contributions from the experts we consulted and the focus group participants. The unpublished technical report (McPake et al. 2013) contains further details of the study.

Open Access This article is distributed under the terms of the Creative Commons Attribution 4.0 International License (http://creativecommons.org/licenses/by/4.0/), which permits unrestricted use, distribution, and reproduction in any medium, provided you give appropriate credit to the original author(s) and the source, provide a link to the Creative Commons license, and indicate if changes were made. 


\section{References}

Abele, F., Dittburner, C., \& Graham, K. (2000). Towards a shared understanding in the policy discussion about Aboriginal education. In M. Brant Castellano, et al. (Eds.), Aboriginal education: Fulfilling the promise. Vancouver: UBC Press.

An Comunn Gaidhealach. (1936). Report of the Special Committee on the Teaching of Gaelic in Schools and Colleges. An Comunn Gaidhealach.

ARAD Consulting. (2011). Research work into the Welsh language Sabbatical Scheme for education practitioners: The use of Welsh made by ex participants in their place of work. Cardiff: ARAD Research.

Artigal, J. M. (1997). The Catalan immersion program. In R. K. Johnson \& M. Swain (Eds.), Immersion education: International perspectives. Cambridge: Cambridge University Press.

August, D., \& Hakuta, K. (Eds.). (1998). Educating language-minority children. Washington, DC: National Academy Press.

Basque Government. (2012). Fifth Sociolinguistic Survey: Basque Autonomous Community, Navarre and Iparralde. Donostia: Vice-Ministry for Language Policy. Available at: http://www.euskara.euskadi. net/r59-738/en/contenidos/informacion/sociolinguistic_research2011/en_2011/adjuntos/Euskal\% 20Herria\%20inkesta\%20soziolinguistikoa\%202011_ingelesez.pdf. Accessed Sept 5, 2013.

Baker, C. (2001). Foundations of bilingual education and bilingualism (3rd ed.). Clevedon: Multilingual Matters.

Baker, C., \& Prys Jones, M. (2000). Welsh language education: A strategy for revitalization. In C. H. Williams (Ed.), Language revitalization: Policy and planning in Wales. Cardiff: University of Wales Press.

Blommaert, J. (1996). Language planning as a discourse on language and society: The linguistic ideology of a scholarly tradition. Language Problems and Language Planning, 20(3), 199-222.

Bòrd na Gàidlig. (2007). The National Plan for Gaelic 2007-2012. Inverness: Bòrd na Gàidhlig. http:// www.gaidhlig.org.uk/Downloads/National-Plan/National\%20Plan\%20for\%20Gaelic.pdf. Accessed July, 262013.

Bòrd na Gàidlig. (2012). National Gaelic Plan 2012-2017: Growth and Improvement. Inverness: Bòrd na Gàidhlig. http://www.gaidhlig.org.uk/Downloads/National\%20Gaelic\%20Langauge\%20Plan\% 202012\%20-\%202017.pdf. Accessed July, 262013.

Bruton, A. (2011). Is CLIL so beneficial or just selective? Re-evaluating some of the research. System, 39, $523-532$.

Campbell, J. (1950). Gaelic in Scottish education and life: Past, present and future. Edinburgh: W. \& A.K. Johnson for the Saltire Society.

Cenoz, J. (2005). English in bilingual programs in the Basque Country. International Journal of the Sociology of Language, 171, 41-56.

Cenoz, J. (2012). Bilingual education policy in higher education in the Basque Country. Language, Culture and Curriculum, 25(1), 41-55.

Cenoz, J., \& Etxague, X. (2011). Third language learning and trilingual education in the Basque Country. In I. Bangma, C. van der Meer, \& A. Riemersma (Eds.), Trilingual Primary Education in Europe: Some developments with regard to the provisions of trilingual primary education in minority language communities of the European Union. Mercator: Ljouwert.

Cenoz, J., Genessee, F., \& Gorter, D. (2013). Critical analysis of CLIL: Taking stock and looking forward. Applied Linguistics,. doi:10.1093/applin/amt011.

Conversi, D. (2002). The smooth transition: Spain's 1978 constitution and the nationalities question. National Identities, 4(3), 223-244.

Council of Europe. (2001). Common European Framework of Reference for Languages: Learning, teaching, assessment. Cambridge: Cambridge University Press. http://www.coe.int/t/dg4/linguistic/ Source/Framework_en.pdf. Accessed July 29, 2013.

Coyle, D., Hood, P., \& Marsh, D. (2010). CLIL: Content and language integrated learning. Cambridge: Cambridge University Press.

Crawford, J. (1998). Endangered native American languages: What is to be done, and why? In T. Ricento \& B. Burnaby (Eds.), Language and politics in the United States and Canada: Myths and realities. Mahwah, NJ: Lawrence Erlbaum Associates.

Dateb. (2007). Evaluation of the National Practitioners' Training Programme and Sabbaticals Scheme. Dateb: Shrewsbury. 
De Korne, H. (2010). Indigenous language education policy: Supporting community controlled immersion in Canada and the US. Language Policy, 9, 115-141.

Dorian, N. C. (1981). Language death: The life cycle of a Scottish Gaelic dialect. Philadelphia: Pennsylvania University Press.

Escobar Urmeneta, C., \& Unamuno, V. (2008). Languages and language learning in Catalan Schools: From the bilingual to the multilingual challenge. In C. Hélot \& A.-M. de Mejía (Eds.), Forging multilingual spaces: Integrated perspectives on majority and minority bilingual education. Bristol: Multilingual Matters.

Ferguson, G. (2006). Language planning and education. Edinburgh: Edinburgh University Press.

Fishman, J. (1976). Bilingual education: An international sociological perspective. Rowley, MA: Newbury House.

Fishman, J. (1991). Reversing language shift. Clevedon: Multilingual Matters.

García, O. (2009). Bilingual education for the 21st century: A global perspective. Chichester: WileyBlackwell.

Gardner, N. (2005). Basque: The Basque language in education in Spain (2nd ed.). Ljouwert: Mercator. http://www.mercator-research.eu/fileadmin/mercator/dossiers_pdf/basque_in_spain2nd.pdf. Accessed September 5, 2013.

Gore, S., \& MacInnes, J. (2000). The politics of language in Catalunya. Scottish Affairs, 30, 96-116.

Gorter, D., \& Cenoz, J. (2011). Multilingual education for European minority languages: The Basque Country and Friesland. International Review of Education, 57, 651-666.

Hamel, E. (2008). Bilingual education for indigenous communities in Mexico. In N. Hornberger (Ed.), The encyclopedia of language and education, Vol. 5: Bilingual education. New York: Springer.

Hinton, L. (2001). Language revitalization: An overview. In K. L. Hale \& L. Hinton (Eds.), The Green Book of language revitalization in practice. San Diego, CA: Academic Press.

Hornberger, N. (2008). Can schools save indigenous languages?. Basingstoke: Palgrave Macmillan.

Huss, L. (2008). Language loss and revitalisation. In K. King \& N. Hornberger (Eds.), Encylopedia of language and education (Vol. 10, pp 69-81).

Idescat (2007). Estadística bàsica de Catalunya: Demografia i qualitat de vida. Coneixement del català. http://www.idescat.cat/dequavi/?TC $=444 \& V 0=15 \& V 1=1$. Accessed June 26, 2013.

Intxausti, N., Etxeberria, F., \& Joaristi, L. (2013). Involvement of immigrant parents in their children's schooling in a bilingual educational context: The Basque case (Spain). International Journal of Educational Research, 59, 35-48.

Jenkins, G., \& Williams, M. (2000). 'Let's do our best for the ancient tongue': The Welsh Language in the twentieth century. Cardiff: University of Wales Press.

Jones, H. (2012). A statistical overview of the Welsh Language. Cardiff: Welsh Language Commissioner. http://www.comisiynyddygymraeg.org/English/Publications\%20List/A\%20statistical\% 20overview\%20of\%20the\%20Welsh\%20language.pdf. Accessed September 5, 2013.

King, K., \& Benson, C. (2004). Indigenous language education in Bolivia and Ecuador: Contexts, changes and challenges. In J. Tollefson \& A. Tsui (Eds.), Medium of instruction policies: Which agenda? Whose agenda?. Mahwah, NJ: Lawrence Erlbaum Associates.

Lambert, W., \& Tucker, G. (1972). Bilingual education of children: The St. Lambert experiment. Rowley, Mass.: Newbury House.

Lasagabaster, D. (nd) Trilingualism at school: The place of English in Basque education. http://www. euskara.euskadi.net/r59-3693/en/contenidos/informacion/artik20_1_trilinguismoa_07_06/en_ trilingu/adjuntos/trilingualismatschool.pdf. Accessed June 26, 2013.

Lindholm-Leary, K., \& Borsato, G. (2006). Academic achievement. In F. Genesee, K. Lindholm-Leary, W. Saunders, \& D. Christian (Eds.), Educating English language learners: A synthesis of research evidence. New York: Cambridge University Press.

López García, A. (2009). La lengua común en la España plurilingüe. Madrid and Frankfurt: Iberoamericana and Vervuert.

Macho Aguillo, G. (2007). In-service teacher training: IRALE, basic features of a renewal project. New Developments in Basque Education in a European Perspective. (Unpublished Seminar Paper). Ljouwert: Mercator.

MacKinnon, K. (1978). Education and social control: The case of Gaelic Scotland. Scottish Educational Studies, 4, 125-137.

MacKinnon, K. (1990). A century on the census: Gaelic in 20th century focus. In D. Thomson (Ed.), Gaelic and Scots in harmony. Glasgow: Department of Celtic, University of Glasgow. http://www. arts.gla.ac.uk/STELLA/STARN/lang/GAELIC/focus.htm. Accessed July 25, 2013. 
Matamua, R. (2012). Evaluation of Whakapiki i te Reo a professional development programme for kaiako in Level 1 and Level 2 Māori medium settings. New Zealand Ministry of Education.

May, (2004). Māori-medium education in Aotearoa/New Zealand. In J. Tollefson \& A. Tsui (Eds.), Medium of instruction policies: Which agenda? Whose agenda?. Mahwah, NJ: Lawrence Erlbaum Associates.

May, S. (2008). Bilingual/immersion education: What the research tells us. In J. Cummins \& N. Hornberger (Eds.), Encyclopedia of language and education (Vol. 5, pp. 19-34).

May, S. (2013). Indigenous immersion education: International developments. Journal of Immersion and Content-Based Language Education, 1(1), 34-69.

May, S., \& Aikman, S. (2003). Indigenous education: Addressing current issues and developments. Comparative Education, 39(2), 139-145.

May, S., \& Hill, R. (2008). Māori-medium education. In N. Hornberger (Ed.), Can schools save indigenous languages?. Basingstoke: Palgrave Macmillan.

McCarty, T. (2002). A place to be Navajo: Rough Rock and the struggle for self-determination in indigenous schooling. Mahwah, NJ: Lawrence Erlbaum Associates.

McCarty, T. (2008). Schools as strategic tools for indigenous language revitalization: Lessons from Native America. In N. Hornberger (Ed.), Can schools save indigenous languages?. Basingstoke: Palgrave Macmillan.

McPake, J., McLeod, W., O’Hanlon, F., Fassetta, G., \& Wilson, M. (2013). Gaelic for Teachers: Design options for a sabbatical course of intensive Gaelic language and pedagogies for qualified teachers wishing to work in Gaelic-medium classrooms. Final Report (unpublished) for Bòrd na Gàidhlig. Available at: https://www.academia.edu/5663989/. Accessed 4 Jan 2016.

McPake, J., Tinsley, T., Broeder, P., Mijares, L., Latomaa, S., \& Martyniuk, W. (2007). Valuing all languages in Europe. Graz (Austria): European Centre for Modern Languages.

Milligan, L., Danson, E., Chalmers, D., Danson, D., \& Neil, M. (2012). The benefits \& opportunities in establishing a National Partnership for Gaelic Medium Initial Teacher Education \& Continuing Professional Development. Inverness: Bòrd na Gàidhlig.

Ministry of Māori Development. (2003). Te Rautaki Reo Māori. The Māori Language Strategy. Wellington: Te Puni Kōkiri and Te Taura Whiri i Te Reo Māori.

Murray, J., \& Morrison, C. (1984). Bilingual primary education in the Western Isles, Scotland. Stornoway: Acair.

Nationalia (2009). Basque is swept away as medium language in schools. http://www.nationalia.info/en/ news/615. Accessed January 31, 2013.

New Zealand Ministry of Education. (2009). Ka Hikitia Managing for success: The Māori education strategy 2008-2012. Summary. New Zealand Ministry of Education.

New Zealand Ministry of Education. (2013a). Budget 2013: Primary and secondary education initiaves. New Zealand Ministry of Education. http://www.minedu.govt.nz/theMinistry/Budget/Budget13/ PrimaryAndSecondary.aspx. Accessed June 22, 2013.

New Zealand Ministry of Education. (2013b). Education counts: Māori language in education. New Zealand Ministry of Education. http://www.educationcounts.govt.nz/statistics/Māori_education/ schooling/6040. Accessed June 26, 2013.

Ó Flatharta, P., Nic Pháidín, C., Williams, C., Grin, F., Lo Bianco, J., \& Nic Chárthaigh, A. (2009). 20Year strategy for the Irish Language. Dublin: Fiontar, Dublin City University.

O'Hanlon, F., Paterson, L., Ormston, R. \& Reid, S. (2013). Public attitudes to Gaelic in Scotland. Edinburgh: University of Edinburgh and ScotCen. http://www.scotcen.org.uk/media/1106939/ soillseresearchdigest3.pdf. Accessed June 26, 2013.

Ó Laoire, M. (2012). Language policy and minority language education: Re-exploring the issues. Language, Culture and Curriculum, 25(1), 17-25.

Office for National Statistics. (2012). 2011 Census: Key statistics for Wales, March 2011. London: Office for National Statistics. www.ons.gov.uk/ons/dcp171778_290982.pdf. Accessed September 5, 2013.

Paterson, L. (2003). Scottish education in the twentieth century. Edinburgh: Edinburgh University Press.

Pérez-Vidal, C., \& Juan-Garau, M. (2011). Trilingual primary education in Catalonia. In I. Bangma, C. van der Meer, \& A. Riemersma (Eds.), Trilingual Primary Education in Europe: Some developments with regard to the provisions of trilingual primary education in minority language communities of the European Union. Ljouwert: Mercator.

Peter, L., Sly, G., \& Hirata-Edds, T. (2011). Using language assessment to inform instruction in indigenous language immersion. In D. Tedick, D. Christian, \& T. Fortune (Eds.), Immersion education: Practices, policies, possibilities. Bristol: Multilingual Matters. 
Petherbridge-Hernandez, P. (1990a). Teacher preparation in a bilingual setting: In-service training for teachers in Catalonia. Journal of Multilingual and Multicultural Development, 11(3), 215-226.

Petherbridge-Hernandez, P. (1990b). The recatalanisation of Catalonia's schools. Language, Culture and Curriculum, 3(2), 97-108.

Pujolar, J. (2010). Immigration and language education in Catalonia: Between national and social agendas. Linguistics and Education, 21(3), 229-243.

Rata, E. (2012). Theoretical claims and empirical evidence in Māori education discourse. Educational Philosophy and Theory, 4(1), 1060-1072.

Robasdan, B. (2006). Foghlam Gàidhlig: bho linn gu linn [Gaelic Education: from one century to the next.]. In W. McLeod (Ed.), Revitalising Gaelic in Scotland. Edinburgh: Dunedin Academic Press.

Sharples, P. (1988). Kura Kaupapa Māori: Recommendations for policy. Auckland: Te Kura o Hoani Waititi Marae.

Sharples, P. (2013). Increased investment in Māori language. New Zealand Government Press Release (16 May). http:/www.scoop.co.nz/stories/PA1305/S00313/increased-investment-in-Māori-language.htm. Accessed June 21, 2013.

Skutnabb-Kangas, T. (1981). Bilingualism or not: The education of minorities. Clevedon: Multilingual Matters.

Spolsky, B. (2008). Riding the tiger. In N. Hornberger (Ed.), Can schools save indigenous languages? Policy and practice on four continents. Basingstoke: Palgrave Macmillan.

Statistics New Zealand. (2007). QuickStats about Māori. Auckland: Statistics New Zealand. www.stats. govt.nz/Census/2006CensusHomePage/QuickStats/quickstats-about-a-subject/maori.aspx. Accessed September 5, 2013.

Stiles, D. (1997). Four successful indigenous language programmes. In J. Reyhner (Ed.), Teaching indigenous languages. Flagstaff: Northern Arizona University (Chapter 21). http://jan.ucc.nau.edu/ jar/TIL_21.html. Accessed August 5, 2013.

Tedick, D., Christian, D., \& Fortune, T. (2011). The future of immersion education: An invitation to 'dwell in possibility'. In D. Tedick, D. Christian, \& T. Fortune (Eds.), Immersion education: Practices, policies, possibilities. Bristol: Multilingual Matters.

Thomas, W. P., \& Collier, V. (2002). A national study of school effectiveness for language minority students' long-term academic achievement. Santa Cruz, CA, and Washington, DC: Center for Research on Education, Diversity \& Excellence.

Tollefson, J. (1991). Planning language, planning inequality: Language policy in the community. London: Longman.

Tomé, M.-J. (2013). Triunfo del Modelo D: 8 de cada diez niños se matriculan en euskera. El Correo (19 February). http://www.elcorreo.com/alava/v/20130219/pvasco-espana/cada-diez-ninos-matriculan20130219.html. Accessed September 5, 2013.

UNESCO. (1953). The use of vernacular languages in education. Paris: UNESCO Publishing.

van der Groot, A. (1996). Bilingual education in Catalonia: Differentiation strategies in primary education. Ljouwert: Mercator.

Webber, J. \& Strubell i Trueta, M. (1991). The Catalan Language. Progress towards normalisation. The Anglo-Catalan Society Occasional Publications. http://www.scribd.com/doc/124829525/Issue07\#download. Accessed June 28, 2013.

Welsh Assembly Government. (2011b). Supporting triple literacy. Language learning in Key Stage 2 and Key Stage 3. Cardiff: Welsh Assembly Government. http://wales.gov.uk/docs/dcells/publications/ 111017literacyen.pdf. Accessed June 26, 2013.

Welsh Government. (2012a). School census results. Cardiff: Welsh Government.

Welsh Government. (2012b). Schools statistics compendium. Cardiff: Welsh Government.

Woolard, K. A. \& Frekko, S. E. (2012) Catalan in the twenty-first century: Romantic publics and cosmopolitan communities. International Journal of Bilingual Education and Bilingualism i-First Article: 1-9.

Zalbide, M., \& Cenoz, J. (2008). Bilingual education in the Basque Autonomous Community: Achievements and challenges. Language, Culture and Curriculum, 21(1), 5-20.

Joanna McPake is Reader in Education at the University of Strathclyde. Her research concerns language learning and teaching, with a particular interest in bilingualism and teacher education for bilingual learning contexts. 
Wilson McLeod is Professor of Gaelic at the University of Edinburgh. His research focuses on minority language policy and planning, with a particular focus on Gaelic in Scotland, and on Gaelic literature and culture from the Middle Ages to the present.

Fiona O'Hanlon is a Chancellor's Fellow in Languages Education at the Moray House School of Education at the University of Edinburgh. Her research relates to language education, language policy and language attitudes in Scotland, with a focus on Scottish Gaelic.

Giovanna Fassetta is a lecturer in intercultural education in the School of Education, University of Glasgow. Giovanna has a background as an educator and taught for over two decades in Italy, Eritrea and the UK. Her research focuses on migration, inclusion and language policies, with a specific interest in the experiences of children and young people.

Mona Wilson is senior lecturer in Gaelic-medium education in the School of Education at the University of Strathclyde. Having worked in this field since 1988, her primary focus in research is on the revitalisation and development of the Gaelic language in Scotland. 